\title{
Evaluation of Dental Anxiety and Fear in Patients who Admitted to the Faculty of Dentistry: Which Patients are More Risky in terms of Dental Anxiety.
}

\author{
Burkay YAKAR ${ }^{1}$, Türkkan Öztürk KAYGUSUZ ${ }^{2}$, Edibe PíRiNÇCI ${ }^{3}$
}

\section{OPEN ACCESS}

Citation: Burkay YAKAR, Türkkan Öztürk KAYGUSUZ, Edibe PİRINÇCI.

Evaluation of Dental Anxiety and Fear in Patients who Admitted to the Faculty of

Dentistry: Which Patients are More Risky in terms of Dental Anxiety. Ethiop J

Health Sci. 2019; 29(6):719.

doi:http://dx.doi.org/10.4314/ejhs.v29 i5.8

Received: July 27, 2019

Accepted: August 09, 2019

Published: November 1, 2019

Copyright: (C2019 Burkay YAKAR, Türkkan Öztürk KAYGUSUZ, Edibe PİRINÇCI. This is an open access article distributed under the terms of the Creative Commons Attribution License, which permits unrestricted use, distribution, and reproduction in any medium, provided the original author and source are credited.

Funding: None

Competing Interests: The authors declare that this manuscript was approved by all authors in its form and that no competing interest exists.

Affiliation and Correspondence:

${ }^{1}$ Frrat University, Faculty of

Medicine, Department of Family

Medicine, Elazığ, Turkey

${ }^{2}$ Frrat University, Faculty of

Medicine, Department of Medical

Education, Elazığ, Turkey

${ }^{3}$ Frrat University, Faculty of

Medicine, Department of Public

Health, Elazığ, Turkey

*Email: byakar@firat.edu.tr
ABSTRACT

Background: Dental anxiety and fear make the dental operation and the treatment difficult. Beside that it causes the delays or absence in the dental appointments so it leads to problems for oral and dental health. The aim of this study was to investigate the frequency of dental anxiety, the factors affecting dental anxiety and the effects of dental anxiety on oral dental health of the participants.

Methodology: We conducted a hospital-based, cross-sectional study among 342 patients attending the outpatient clinic of a tertiary dentistry hospital. Dental anxiety and trait anxiety levels of the participants measured using MDAS and STAI scales. We conducted the student t-test, One-way Anova and Tukey's post hoc for the analysis of our data. The Pearson's correlation analysis has been used for the analysis of two different quantitative data obtain from MDAS and STAI scales.

Results: The age average of 342 participant of our research was $34,41 \pm 11,78$. $59,1 \%$ of our participants was women. $(n=202)$ Dental anxiety was existing in the $42,1 \%$ of the participants $(n=144) .56,4 \%$ of the participants have had a hard and painful dental treatment experiences. $15,2 \%$ of our participants $(n=52)$ had MDAS 19 point or more.

Conclusions: High and statistically significant dental anxiety scores have been detected for the patients who are women, housewives, who had uneasy and painful dental treatment stories, who have personel inclinations to the anxiety. Examinations directed to the factors which would increase the dental anxiety, may prevent possible complications and also the risk carried by the patients related to the dental health may be estimated with the help of this kind of examinations.

Keywords: Dental anxiety, MDAS, STAI, dental fear, dental health

\section{INTRODUCTION}

Dental anxiety has been identified as a fear and anxiety situation occurred in patients against the stress of the dental operation, specifically generated for the dental interventions (1).

At the present time, current researches show the dental anxiety is still a problem despite the modern and technological developments at the dentistry area. In the studies conducted in order to identify the 
frequency of dental anxiety, the findings show that dental anxiety is seen with a rate of $21,3 \%-23,5 \%$ in the Turkish society. This rate is between 2,5\% and $20 \%$ for the other populations. Especially for the population of young Saudies, dental anxiety frequency is $39 \%(2-5)$. Although there are many studies about the dental anxiety, it is reported that there is no exact result for the dental fear and anxiety levels because of the different cultures and traditions of the societies (6).

Dental anxiety which seen frequently, makes the dental operations hard for dentists and makes the treatment difficult, and it is reported that thedental anxiety and fear, are major obstacles for the protenction of dental health $(7,8)$. Dental anxiety and fear, cause the delays or absence in the dental appointments. It is shown in the researches, the patients who have dental anxiety and fear experience less dental health problem than the patients who have not dental anxiety and fear $(9,10)$.

If the factors cause the dental anxiety and fear are known, it may decrease the anxiety levels for the dental examinations and may help the patients for an efficient and easy dental examination. It is reported that the environmental and psychological factors take role in the occurrence of dental anxiety (11). In the literature, it is shown that the dental anxiety has been affected by the age, gender, marital status, education level, occupation, personel inclination and the painful experiences during the dental treatments (12-15). In the studies conducted for Turkey and the other countries, it is reported that woment have more dental anxiety and fear than men $(3,16,17)$. Beside that, more frequent dental anxiety reported for the singles and members of lower education and socioeconomic levels (16).

As a result of data obtained from literature, it has been seen the dental anxiety is a widespread problem in the society and causes the delays for the dental examinations and enables the impairments of dental hygiene. At the same time, the dental anxiety and fear makes the dental examination uneasy and may cause the complications during the operations. In this context, if the dentists know the factors caused the dental anxiety before the treatment, and take precautions which may lower the anxiety and fear, it makes the dental operations more easy and prevent the complications which may occur.

Now a days, dental anxiety and fear have a negative impact on oral and dental health. It also causes complications and cost increases. In the light of data, we aimed to research the frequency of dental anxiety and factors which may cause dental anxiety for the patients who applied our dentistry clinic. We believe that the results obtained can also be used to reduce dental anxiety.

\section{MATERIALS AND METHODS}

The Type of Research: The population of our cross-sectional research formed by all the patients applied to the faculty of dentistry between the dates of August 2018 and October 2018, who are volunteer and matching our criteria. Since the size of the universe is not known, the sample size is calculated from the formula $\left(n=t^{2} * p^{*} \mathrm{q} / \mathrm{d}^{2}\right)$ in calculating the sample size. The incidence of dental anxiety was reported as $20 \%$ in literatur so we made a sample calculation by accepting $20 \%$ incidence of dental anxiety (3). It was found that at least 245 people should be included in the study. Our study was carried out with more than this number of participants. Our research has been started after the permission of hospital chief physician and the assize which dated 19.07.2018 and numbered 13/02 of the Firat University Faculty of Medicine Noninvasive Researches Ethical Commitee.

Data Collection Tools:A socio-demographic questionnaire form which contains twelve questions formed by the literature review has been used in order to obtain the independent variables of our study.

In order to measure the dental anxiety scores and trait anxiety situations which are the dependent variables of our study, modified dental anxiety scale and trait anxiety inventory have been used. All questionnaire forms were read to the participants by the researcher and asked to answer the questions. Firstly, questionnaire forms were applied to a group of 20 participants and the intelligibility of the questions were evaluated thanthese data were included in the study. In general, all questions were answered by the participants. The average time to answer all questionnaire forms were 15 minutes. The same

DOI: http://dx.doi.org/10.4314/ejhs.v29i6.8 
researcher then applied the questionnaire forms to all participants.

Modified dental anxiety scale (MDAS) formed by the Humphris et al. in 1995 and used for the evaluation of dental fear and anxiety (18). A questionnaire which formed by five questions, and filled by the participants themselves, examines specifically dental anxiety. The first four questions of MDAS, produced upon the bases of Dental Anxiety Scale (DAS) and fifth question planned in order to measure the fear and anxiety against an injection into the mouth.

Each questions of the questionnaire contains five scores varies between no perturbation and excessive perturbation in order to measure the perturbation level of participants. Minimum 1 and maximum 5 scores are obtained by each question and minimum 5 and maximum 25 scores are obtained by the whole questionnaire. Ilgun et al. (2005) conducted a study to measure the validity and reliability of MDAS for Turkey and it is reported that MDAS is valid and reliable for our country. MDAS Turkish questionnaire, Cronbach's alpha was 0.81 and the distribution of answers to each question was found to be normal. The cut-off score is 19 for MDAS and 19 and plus scores show high level of dental anxiety (19).

In our study, Situational-Trait Anxiety Inventory (STAI), Subjective Self Perception Tests have been conducted to evaluate trait anxiety levelts independent from dental anxiety. STAI, is an inventory developed by Speilberger and Gorsuch (1964) in order to measure the trait and situational anxiety levels in the normal and abnormal individuals. Necla Oner has showed its validity for the Turkish society and it has been transleated into Turkish as "Durumluk-Sürekli Kayg1 Envanteri" (20). Öner et al. reported that the trait anxiety inventory Cronbach's alpha score was 0.83 and the state anxiety inventory Cronbach's alpha score was 0.94 . STAI measures the levels of situational and trait anxiety and has two different scale formed by twent articles. STAI is an easy inventory which individuals can answer themselves. Both of scales can be applied at the same time. If the inventory applied to individuals who are illiterate, articles are read by applier and answers are transferred into the form by the applier again. It can be applied to individuals who are conscious and older than fourteen. It is reported that there is no need to a special training to apply this test (21). In our study, only trait anxiety scale has been used to measure the trait anxiety levels of participants.

In the response of trait anxiety scale, according to the feelings, thoughts or behaviours expressed by articles, it is demanded to choose and mark one of those options; "Almost never", "Sometimes", "Many times", and, "Almost always". There are direct and reversed expressions in the scales. In the expressions which are positive (reversed), 4 valued answers show lower anxiety and 1 valued answers show higher anxiety. While these expressions converted into the scores, 1's get 4 value and 4's get 1 value. In the direct expressions point negative feeelings, 4 valued answers show highest anxiety. In the end of questionnaire, higher scores of participants mean the higher level of anxiety.

The data are collected by the dentists in the dentistry policlinic by using socio-demographic questionnaire, MDAS form and STAI inventory with the face to face meeting technique.

All the individuals who are volunteer and older than 18 included into our study. The individuals who are not volunteer, younger than 18 yeasr old, having recognized anxiety, receiving anxiety treatment, having psychiatric or neurological diseases which prevents communication and evaluation of questionnaire are excluded from our study.

Our study has been conducted after taking necessary permissions from related faculty administration and from the ethical committee of Firat University.

Data Analysis: The obtained data by our study has been analysed and presented with the SPSS 22.0 (SPSS for Windows, version 22.0, SPSS Inc., Chicago,IL, USA) programme by conducting error controls, descriptive tables and statistical analysis. Descriptive data presented as \pm ; percents and averages. Dual variables tested by student t-test, and multi-variables tested by One-way Anova and Tukey's post hoc analysis. In the analysis of two different numeric data obtained by MDAS and STAI scales, Pearson's corelation analysis has been used.We have considered the data 
statistically significant in the $95 \%$ confidence interval and $p<0,05$.

\section{RESULTS}

The mean age of 342 participants included in our study was $34.41 \pm 11.78(\min =18 \max =74)$. $59.1 \%$ of the participants were female $(\mathrm{n}=202)$ and $40.9 \%(\mathrm{n}=140)$ were male. $62.9 \%(\mathrm{n}=215)$ of the participants were married. When we examine the occupations of the participants, housewives were the largest group with $28.4 \%$. It was seen that $83.6 \%$ of the participants perceived their income levels as sufficient (Table 1).

Table 1. Descriptive features of the participants.

\begin{tabular}{|c|c|c|}
\hline Variable & $\begin{array}{l}\text { Number } \\
\text { (n) }\end{array}$ & $\begin{array}{l}\text { Percent } \\
(\%)\end{array}$ \\
\hline \multicolumn{3}{|l|}{ Gender } \\
\hline Female & 202 & 59,1 \\
\hline Male & 140 & 40,9 \\
\hline \multicolumn{3}{|l|}{ Marital status } \\
\hline Married & 215 & 62,9 \\
\hline Single & 127 & 37,1 \\
\hline \multicolumn{3}{|l|}{ Occupation } \\
\hline Housewife & 97 & 28,4 \\
\hline Officer & 80 & 23,4 \\
\hline Employee & 93 & 27,2 \\
\hline $\begin{array}{r}\text { Unemployed and } \\
\text { student }\end{array}$ & 72 & 21,1 \\
\hline \multicolumn{3}{|l|}{ Income } \\
\hline Insufficient & 56 & 16,4 \\
\hline Sufficient & 286 & 83,6 \\
\hline \multicolumn{3}{|l|}{ Age } \\
\hline$<40$ year & 230 & 67,3 \\
\hline$\geq 40$ years & 112 & 32,7 \\
\hline \multicolumn{3}{|l|}{ Educational level } \\
\hline $\begin{array}{r}\text { Did not finish high } \\
\text { school }\end{array}$ & 81 & 23,7 \\
\hline Finished high school & 261 & 76,3 \\
\hline
\end{tabular}

Of the participants, $42.1 \%(n=144) \quad$ had fear of dentist. $56.4 \%$ of the participants had a history of painful and hard dental examination. The most common cause of admission to the dentist $26.0 \%$ of the participants was tooth filling. $78.9 \%$ of the participants were applying to the dentist as long as they had complaints. $36.8 \%$ of the participants brushed their teeth once a day. The most common bad habits affecting the dental health were smoking with $27.5 \%$ (Table 2).
Table 2. Distribution of attitudes and behaviors of the participants about oral health.

\begin{tabular}{crr}
\hline Variable & Number & Percent \\
\hline $\begin{array}{c}\text { Fear of dental examination } \\
\text { Yes }\end{array}$ & 144 & 42,1 \\
No & 198 & 57,9 \\
$\begin{array}{c}\text { Painful and difficult tooth } \\
\text { extraction experience }\end{array}$ & & \\
Yes & 194 & 56,7 \\
No & 148 & 43,3
\end{tabular}

Cases presented at the clinic

Tooth extraction Filling

$77 \quad 22,5$

Dental canal treatment

Dental prosthesis

Dental surgery

Check-examination

Inspection frequency

First

8926,0

$45 \quad 13,2$

$23 \quad 6,7$

$40 \quad 11,7$

$68 \quad 19,9$

When I have a complaint

Every 6 months

Every 1 years

\section{Tooth brushing habit}

Irregular $\quad 107 \quad 31,3$

Regular brushes once a day $\quad 126 \quad 36,8$

2 times a day $\quad 86 \quad 25,2$

3 times a day $\quad 23 \quad 6,7$

Bad habits for dental health

\begin{tabular}{crr} 
Smoking & 94 & 27,5 \\
Alcohol & 3 & 0,9 \\
Tooth squeezing & 34 & 9,9 \\
Nail biting & 14 & 4,1 \\
Hard thing biting & 27 & 7,9 \\
Not & 170 & 49,7 \\
\hline
\end{tabular}

The mean score of the participants from the Modified Dental Anxiety Scale (MDAS) was $13.13 \pm 4.48(\min =5 \max =25)$. Of the participants, $15.2 \%(\mathrm{n}=52)$ had MDAS score of 19 and over with dental anxiety. The mean score of trait anxiety was $44.33 \pm 8.29(\min =22, \max =$ 65 ). The history of dental fear and difficult dental examination was significantly higher in patients with dental anxiety. $(p<0,005)$ (Table 3$)$. 
Table 3. The relation of dental anxiety with dentist fear and hard dental examination.

\begin{tabular}{lccccccc}
\hline \multicolumn{2}{c}{ No dental anxiety } & \multicolumn{2}{c}{ Dental anxiety } & Total & & P Value \\
\hline \multicolumn{2}{c}{$\begin{array}{c}\text { Number } \\
\text { Fear of dental examination }\end{array}$} & Percent & Number & Percent & Number & Percent & \\
$\quad$ Yes & 99 & 68,8 & 45 & $31,2 \%$ & 144 & 100 & \\
No & 191 & 96,5 & 7 & $3,5 \%$ & 198 & 100 & $\mathbf{p}<\mathbf{0 , 0 0 1}$ \\
$\begin{array}{l}\text { Painful and difficult tooth } \\
\text { extraction experience }\end{array}$ & & & & & & \\
Yes & 152 & 78,4 & 42 & 21,6 & 194 & 100 & \\
No & 138 & 93,2 & 10 & 6,8 & 148 & 100 & $\mathbf{p}<\mathbf{0 , 0 0 1}$ \\
\hline
\end{tabular}

When we evaluated the relationship between sociodemographic characteristics and dental anxiety scores, MDAS scores were significantly higher in women, those with fear of dentists and in patients with painful dental examinations in the past $(\mathrm{p}<0.001)$. Dental anxiety scores were higher in the housewives than the officers and unemployed participants. When we examined the effect of bad habits on MDAS scores, MDAS scores of those with teeth grinding were statistically higher than cigarette users. The trait anxiety score was significantly higher in women, over 40 age, married, insufficient income, low education and participant with dental fear $(p<0,05)$. Trait anxiety scores was higher in participants who went to irregular dentist control than those who regularly visited $(\mathrm{p}<0,01)$ (Table 4).

Table 4. Relationships some variable with MDAS and STAI score.

\begin{tabular}{|c|c|c|c|c|c|c|c|}
\hline Variable & Number & MDAS Se & & Statistics & STAI Scor & & Statistics \\
\hline Gender & & Mean & Std. Deviation & & Mean & Std. Deviati & \\
\hline Female & 202 & 14,27 & 4,52 & $\mathrm{t}=\mathbf{5 , 8 9}$ & 45,14 & 8,53 & $\mathrm{t}=2,19$ \\
\hline Male & 140 & 11,50 & 3,89 & $\mathbf{p}<0,001$ & 43,18 & 7,58 & $\mathrm{p}=\mathbf{0 , 0 3}$ \\
\hline \multicolumn{8}{|l|}{ Age } \\
\hline$<40$ years & 230 & 13,30 & 4,43 & $\mathrm{t}=0,98$ & 43,59 & 8,14 & $t=2,44$ \\
\hline$\geq 40$ years & 112 & 12,79 & 4,57 & $\mathrm{p}=0,33$ & 45,88 & 8,14 & $\mathrm{p}=\mathbf{0 , 0 2}$ \\
\hline \multicolumn{8}{|l|}{ Educational level } \\
\hline Under high school & 81 & 13,49 & 4,42 & $\mathrm{t}=0,83$ & 46,85 & 8,88 & $\mathbf{t}=\mathbf{3 , 2 0}$ \\
\hline High school & 261 & 13,02 & 4,50 & $\mathrm{p}=0,41$ & 43,56 & 7,83 & $\mathbf{p}<\mathbf{0 , 0 0 1}$ \\
\hline \multicolumn{8}{|l|}{ Marital status } \\
\hline Married & 215 & 13,36 & 4,56 & $\mathrm{t}=1,23$ & 45,08 & 8,58 & $t=2,19$ \\
\hline Single & 127 & 12,75 & 4,32 & $\mathrm{p}=0,22$ & 43,08 & 7,37 & $\mathrm{p}=\mathbf{0 , 0 3}$ \\
\hline \multicolumn{8}{|l|}{ Income } \\
\hline Insufficient & 56 & 13,30 & 4,32 & $\mathrm{t}=0,31$ & 46,98 & 8,75 & $t=2,66$ \\
\hline Sufficient & 286 & 13,10 & 4,51 & $\mathrm{p}=0,76$ & 43,82 & 8,00 & $\mathrm{p}=\mathbf{0 , 0 0 8}$ \\
\hline \multicolumn{8}{|c|}{ Fear of dental examination } \\
\hline Yes & 144 & 15,59 & 4,19 & $t=9,98$ & 45,40 & 9,05 & $t=2,06$ \\
\hline No & 198 & 11,35 & 3,78 & $\mathbf{p}<\mathbf{0 , 0 0 1}$ & 43,56 & 7,45 & $p=0,04$ \\
\hline
\end{tabular}

In our study, we examined the effects of trait anxiety on dental anxiety. There was a weak but statistically significant correlation between trait anxiety scores and dental anxiety scores $(\mathrm{p}<0,001)$ (Table 5). 
Table 5. Relationship between trait anxiety and dental anxiety score.

\begin{tabular}{lcl}
\hline & \multicolumn{1}{c}{ STAI score } & \multicolumn{1}{c}{ MDAS score } \\
\hline STAI score & 1,000 & $\mathrm{r}=235^{* *}$ \\
& & $\mathrm{p}<.001$ \\
& $\mathrm{r}=235^{* *}$ & 1,000 \\
MDAS score & $\mathrm{p}<.001$ & \\
& Correlation is significant at the 0.01 level (2-tailed). $\mathbf{r}=$ spearmans's correlation coefficient \\
\hline
\end{tabular}

\section{DISCUSSION}

It was observed that the frequency of dental anxiety was significantly higher in women than men. Nearly all of the literature surveys reported that female gender was a risk factor for dental anxiety $(6,15,22,24,25)$. The data we obtained were consistent with the literature and the frequency of dental anxiety was significantly higher in women. In our study, it was observed that educational status and marital status did not have a statistically significant relationship with dental anxiety. In the literature, while there is a decrease in the level of education in the literature, there are no significant relationship between education levels and dental anxiety scores. Our study failed to explain the relationship between education level and dental anxiety $(25,28)$.

Y1ldirım et al. reported that there was no relationship between marital status and detal anxiety levels and Egbor et al. found that dental anxiety was higher in singles $(25,29)$. The data obtained by Egbor et al. although it is contradictory with our data, it is thought that the relationship between marital status and dental anxiety should be investigated further.

In literature data, it was reported that dental anxiety scores were higher in younger ages $(15,22,30)$. In our study, although not statistically significant, dental anxiety scores were found to be higher in individuals under 40 years of age. It has been reported that dental anxiety decreases as people get older, depending on their previous experience (24). In our data, the high level of dental anxiety score under 40 years of age was similar to this hypothesis.

In our study, dental anxiety rates were higher in housewives than other groups. In the majority of literature, there was no significant relationship between occupational and dental anxiety and our findings could not be supported by literature data
(15). In a study conducted in the Indian population, dental anxiety in housewives and students was found to be significantly higher than other occupational groups and found to be consistent with the data we obtained (24).

In our study, dental anxiety was found more frequently in women, so dental anxiety in housewives may be more frequent in housewife. Considering this situation, it may be useful to investigate the relationship between occupation and dental anxiety in subsequent studies.

Locker et al. reported that painful dental experience is the most important determinant of dental anxiety (31). When we examine the literature data, it has been reported that bad experiences in the past increased dental anxiety $(26,30)$. The data we obtained were similar with the literature and it was thought that bad experiences in the past were statistically significant with dental anxiety levels. According to our data and literature, it can be said that the experience of difficult dental examination in the past is an important determinant of dental anxiety. In the literature, it has been reported that dental anxiety leads to disruptions in dental visits and oral hygiene $(24,26)$. In our study, it was observed that the frequency of dentist control decreased and the brushing habits were irregular when the dental anxiety score increased. Our findings are consistent with the literature findings, and dental anxiety has a negative effect on the oral and dental health of individuals.

The literature also suggests that the relationship between continuous anxiety and dental anxiety is weak correlation in some research and strong correlation in other research (32-34).

Mendez et al. reported that continuous anxiety may be a predisposing factor for dental anxiety (34). Correlation between dental anxiety and trait anxiety in our study, it was suggested that dental

DOI: http://dx.doi.org/10.4314/ejhs.v29i6.8 
anxiety could be seen more frequently in patients with continuous anxiety.

When we investigate the literature data, it is reported that dental and continuous anxiety are higher in females than males $(33,35)$. As expected, both dental and trait anxiety were found to be high in women in our study. Based on this data, it was thought that dentists should be more careful in terms of anxiety in female patients. In our study, the effects of other sociodemographic characteristics on both dental and trait anxiety were not observed. There was a significant relationship between age, education, marital status, income level and trait anxiety, but no statistically significant effect on dental anxiety.

Fuentes et al. it was emphasized that only female sex affects both dental and trait anxiety and dental anxiety has different specific characteristics from trait anxiety (33). In our study, the literature data was supported and it was found that the factors affecting both anxiety differed despite the positive correlation between dental and trait anxiety.

According to the data obtained from our study, it is thought that the factors affecting both anxiety levels are well known and also the factors that may cause dental anxiety can help patients overcome their anxiety and provide better dental health and treatment.

Dental anxiety increases the likelihood of complications during dental intervention, as well as impairing the oral and dental health of people. Dental anxiety scores increase in women, housewives, young patients, those with a history of painful and difficult dental examinations, those who declare a fear of dentist and those with anxiety disorders. It has been observed that dental anxiety individuals may have a negative effect on the tooth examination and oral health. We can prevent possible complications by questioning the factors that may cause anxiety in the patients before dental examination and we can estimate the risk of the people in terms of oral health.

\section{ACKNOWLEDMENTS}

We sincerely thank management of Firat Faculty of Dentistry.

\section{REFERENCES}

1. Weiner A.A. The fearful dental patient. A guide to understanding and management. Oxford, England, UK: Blackwell Publishing Ltd; 2011.

2. Armfield JM, Spencer AJ, Stewart JF. Dental fear in Australia: who's afraid of the dentist? Aust Dent J. 2006;51(1):78-85.

3. Firat D, Tunc EP, Sar V. Dental anxiety among adults in Turkey. $J$ Contemp Dent Pract.2006 Jul 1;7(3): 75-82.

4. Moore R, Birn H, Kirkegaard E, Brødsgaard I, Scheutz F.Prevalence and characteristics of dental anxiety in Danish adults. Community Dent Oral Epidemiol. 1993 Oct;21(5):292-296.

5. Quteish Taani DS. Dental fear among a young adult Saudian population.Int Dent J. 2001 Apr;51(2):62-6. https://doi.org/10.1002/j.1875595X.2001.tb00823.X

6. Bodrumlu E, Sümer A.P, Sümer M, Köprülü H. Ondokuz Mayıs Üniversitesi Dişhekimliği Fakültesine Başvuran Bireylerde Dental Korkunun Değerlendirilmesi. Journal of Hacettepe Faculty of Dentistry. 2006; 30(1) : p51-56

7. Schwarz E. Dental anxiety in young adult Danes under alternative dental care programs. Scand J Dent Res. 1990;98:442-450

8. Milgrom P, Fiset L, Melnick S, Weinstein P. The prevalence and practice management consequences of dental fear in a major US city. $J$ Am Dent Assoc. 1988; 116:641-647.

9. Locker D, Poulton R, Thomson WM. Psychologicaldisorders and dental anxiety in a young adult population.Community Dent Oral Epidemiol. $2001 \mathrm{Dec} ; 29(6)$ :456-63.

10. Abrahamsson KH, Berggren U, Carlsson SG. Psychosocialaspects of dental and general fears in dental phobicpatients. Acta Odontol Scand. 2000;58:37-43.

11. Vesa Pohjola, Satu Lahti, Miira M. Vehkalahti, Mimmi Tolvanen \& Hannu Hausen Association between dental fear and dental attendance among adults in Finland. Acta Odontologica Scandinavica. 2007: 65(4); 224-230

12. Marakoğlu I, Demirer S, Özdemir D, Sezer H. Level of statetrait anxiety iventory before periodontal treatment. Cumhuriyet Dental Journal. 2003;6(2):73-79.

13. Köroglu A, Durkan R. An evaluation of the etiology and the treatment procedures of dental

DOI: http://dx.doi.org/10.4314/ejhs.v29i6.8 
anxiety syndrome en countered in dental applications. $J$ Dent Fac Atatürk Univ. 2010;3(20):205-12.

14. Armfield JM, Pohjola V, Joukamaa M, Mattila AK, Suominen AL, Lahti SM. Exploring the associations between somatization and dental fear and dental visiting. Eur $J$ Oral Sci. 2011;119(4):288-93.

15. I. Astramskaite, L. Poskevicius, G. Juodzbalys: Factors determining tooth extraction anxiety and fear in adult dental patients: a systematic review. Int. J. Oral Maxillofac. Surg. 2016; 45: 16301643.http://dx.doi.org/10.1016/j.ijom.2016.06.01 9

16. Erten H, Akarslan ZZ, Bodrumlu E. Dental fear and anxiety levels of patients attending a dental clinic. Quintessence Int. 2006;37(4):304-310.

17. Marya CM, Grover S, Jnaneshwar A, Pruthi N. Dental anxiety among patients visiting a dental institute in Faridabad, India. West IndianMed $J$. 2012;61(2):187-190.

18. Humphris GM, Morrison T, Lindsay SJ. Modified Dental Anxiety Scale: validation and United Kingdom norms. Community Dent Health. 1995; 12:143-150.

19. D Ilgüy, M Ilgüy, S Dinçer et al. Reliability and Validity of the Modified Dental Anxiety Scale in Turkish Patients. The Journal of International Medical Research. 2005; 33: 252 - 259

20. Öner N, Le Compte A. State Trait Anxiety Inventory Handbook. 1. Ed, İstanbul, Boğaziçi University Publications, 1983.

21. Aydemir Ö, Köroğlu E. (Clinical Scales Used in Psychiatry) Psikiyatride Kullanılan Klinik Ölçekler. Ankara: Hekimler Yayın Birliği. 2006; p:153-63

22. Marian A Ofori, F Adu-Ababio, E A Nyako, Tom A Ndanu. Prevalence of dental fear and anxiety among patients in selected dentalclinics in Ghana. Health Education Journal. 68(2) 2009 130-139.

23. Milgrom P, Fiset L, Melnick S, Weinstein P. The prevalence and practice management, consequences of dental fear in a major US city. $J$ Am Dent Assoc, 1988: 116: 641-7.

24. S. Acharya. Factors affecting dental anxiety and beliefs in an Indian population. $J$ Oral Rehabil. $2008 \quad$ Apr; 35(4): 259267. doi: 10.1111/j.1365-2842.2007.01777.x

25. Yıldırım TL, Kaya FA, Uysal E. Diş Hekimi Korkusu ile Cinsiyet, Yaş, Medeni Durum, Diş Hekimine Gitme Sıklığı, Eğitim, Sosyo-
Ekonomik ve Periodontal Durum Arasındaki İlişkinin İncelenmesi. Turkiye Klinikleri J Dental Sci. 2013;19(2): 77-85

26. Ay ZY, Erdek Y, Öztürk M, Kılınç G, Bozkurt Y, Yılmaz R. Süleyman Demirel üniversitesi diş hekimliği fakültesine başvuran hastalarda dental korku düzeyinin incelenmesi. Cumhuriyet Üniversitesi Diş Hekimliği Fakültesi Dergisi. 2005;8(1):12-18

27. Haugejorden O, Klock KS. Avoidance of dental visits: the predictive validity of three dental anxiety scales. Acta Odontol Scand. 2000 Dec;58(6):255-9.

28. Ay S, Özdemir D, Öztürk M, Polat S. An assessment of dental anxiety in oral surgery patients. Gülhane Tip Dergisi. 2002;44 (4) : 395 398

29. Egbor PE, Akpata O. An evaluation of the sociodemographic determinants of dental anxiety in patients scheduled for intra-alveolar extraction. Libyan J Med. 2014;9:25433.

http://dx.doi.org/10.3402/ljm.v9.25433.

30. Doganer YC, Aydogan U, Yesil HU, Rohrer JE, Williams MD, Agerter DC. Does the trait anxiety affect the dental fear? Braz Oral Res. 2017;4;31-36. doi: 10.1590/1807-3107BOR2017.vol31.0036.

31. Locker D, Shapiro D, Liddell A. Negative dental experiences and their relationship to dental anxiety. Community Dent Health. 1996 Jun;13(2):86-92.

32. Okawa K, Ichinoche T, Kaneko Y. Anxiety may enhance pain during dental treatment. Bull Tokyo Dent Coll. 2005; 46: 51-58.

33. Fuentes D, Gorenstein C, Hu LW. Dental anxiety and trait anxiety: an investigation of their relationship.Br Dent J. 2009 Apr 25;206(8):E17.

34. Lago-Méndez L, Diniz-Freitas M, Senra-Rivera C, Seoane-Pesqueira G, Gándara-Rey JM, Garcia-Garcia A. Dentalanxiety before removal of a third molar and association withgeneral trait anxiety. $J$ Oral Maxillofac Surg. 2006;64(9):1404-8. https://doi.org/10.1016/j.joms.2006.05.030

35. Fábián $\mathrm{G}$, Müller $\mathrm{O}$, Kovács $\mathrm{S}$ et al. Attitude toward death. Does it infl uence dental fear? Ann N Y Acad Sci. 2007; 1113: 339-349. 